\title{
A Fine Line: Being an Out Transsexual Woman
}

\author{
TERI JANE URSACKI-BRYANT
}

Teri Jane Ursacki-Bryant is an Associate Professor in the Haskayne School of Business at the University of Calgary. She has taught international business there since 1990. Her research interests focus on Japanese executive management practices, Japanese-Canadian trade and other Asian management issues. After struggling with transgender issues since childhood, she initiated physical preparations for gender reassignment in January, 1998, began living as a woman in June, 1999, and underwent gender reassignment surgery in June, 2000. Her life is the subject of an instructional video entitled "A Transgender Journey: Workplace and Lifestyle Management." Since writing this article she has married the partner referred to in the concluding paragraph.

I started cross-dressing when I was very young. I told no one until I was in my mid 30s, when I disclosed my status to a few close friends and relatives and to my Dean. By that time I was venturing out in public quite often. I knew there was always a risk that they would hear something 'through the grapevine' and I wanted to control what they heard. For the most part, though, I felt there was no need to tell others.

Once I was able to begin preparing for a full-time transition to living as a woman, I really had no choice about being out to everyone around me. I was staying in the same workplace, so it was unavoidable that all my colleagues would know about my transition. I spent a lot of time preparing them, having one-on-one meetings with over a hundred people. Some of these meetings lasted as much as two hours, as I outlined what was going to happen and responded to questions. My colleagues were very supportive. 
I had students who had me for one course as a man and then for another the next year as a woman: there was no keeping the secret from them! I did not discuss my personal life in class, but I did prepare a variety of ways that students could access information about what was going on. I prepared a handout with background transgender information that was available from several sources around the Faculty, created a web site, and obtained the agreement of a volunteer who was able to respond to any student enquiries. I also offered to discuss matters personally outside of class hours with anyone who wanted to do so and later had an article about myself published in the Faculty's student newspaper. In class I did not discuss my situation at all: I simply alluded to it elliptically and pointed out how people could find out more if they wanted to. My students seemed to react well: my student evaluations remained high and my classes remained near capacity.

I also informed my neighbors, who took the news well. I had made a habit of cultivating good relations with them by shoveling snow, raking leaves, cleaning up the alley and so on, and this stood me in good stead when I needed a little understanding.

At first I thought that in the broader community everyone would know I was a transsexual woman due to my height (6'3") and general physical experience. I saw no real downside to being open in private fora, such as groups of students or caregivers. I definitely didn't want mass media attention. However, at one point I was put under considerable stress by the Calgary Herald, which outed me in its pages shortly before I began living as a woman.

As things turned out, the physical changes from my cosmetic surgeries and other procedures have meant that few people identify me as a transsexual woman unless they know already or are told. This confronted me with a dilemma: should I just lay low and preserve my acceptance as a woman or take the risk of drawing unwanted attention and speak out? Even speaking in private risked attracting the attention of the media, which tends to deal with such issues in a rather sensationalistic manner. For a while I contemplated stopping my speaking engagements. A major worry for me was the reaction of possible suitors. I knew I wanted to find a life partner, and I felt the more public I was, the more difficult it would be for him to deal with having a transsexual partner. 
In the end I decided to continue speaking, at least for now. The reaction I get from audiences tells me I have a message that people appreciate hearing, and I have now met a wonderful partner who is very supportive and completely open to me speaking in public (he has even attended a panel discussion I participated in). Many transgendered people have told me they think it is very important to have 'out' transgendered people in visible roles to show that it is possible to have a successful and productive life. I speak openly about my situation to classes of students studying sexual issues and groups of people who may have to deal with transgendered people in the workplace and I maintain an extensive web site that gets hundreds of hits a week and attracts a steady stream of transgendered people seeking advice. I also tell most of those who are close to me, such as friends, ministers, etc. For me the issue involves walking a fine line as I try to contribute to the education of society and fulfil my responsibility to the transgendered community while at the same time preserving some semblance of privacy. 